See discussions, stats, and author profiles for this publication at: https://www.researchgate.net/publication/233272303

\title{
The governance of local development: An assessment of organizational capacity in North West Europe
}

Article in Planning Practice and Research · May 2006

Dol: 10.1080/02697450600944665

CITATION

7 authors, including:

Valery Michaux

NEOMA Business School

16 PUBLICATIONS 35 CITATIONS

SEE PROFILE
READS

35

Fabrice Thuriot

Université de Reims Champagne-Ardenne

24 PUBLICATIONS 3 CITATIONS

SEE PROFILE

Some of the authors of this publication are also working on these related projects:

Project Impact of Canadian Parties View project

Project People and Place: A Census Atlas of the Republic of Ireland View project 


\title{
The Governance of Local Development: An Assessment of Organizational Capacity in North West Europe
}

\author{
DOMINIQUE DECOSTER, VALERY MICHAUX, \\ MICHAEL MURRAY, BRENDAN MURTAGH, \\ CATHERINE NIARCHOS, FABRICE THURIOT \& JIM WALSH
}

\section{Introduction}

Many of Europe's regions and localities have traditionally relied for their development on central government policy intervention and large-scale enterprise (Stohr, 1990). However, over the past 25 years they have adjusted these preferences by more fully embracing local action. Today, the theory and practice of local development emphasize its potential to identify and harness a wide variety of resources in ways that are often more effective and efficient than top-down initiatives acting alone. This approach requires appropriate governance arrangements that are strongly supportive, not least politically, of local activity. It requires the formation and operation of local level alliances by stakeholders who can think and act strategically within organizational structures whose missions have been shaped by those whom local development programmes are intended to benefit. And of course, it is vital that the scope of local development is defined as a multi-dimensional set of activities that recognize the interdependence not just of social, economic, cultural and environmental measures, but also the very real connectedness between people and place. Spatial development approaches to local development are, therefore, an important element of any coherent local development framework.

The latter point is especially important in that strategic spatial planning at multiple scales is now very much in vogue across Europe. Albrechts et al. (2003) have argued that 'strategic frameworks and visions for territorial development, with an emphasis on place qualities and the spatial impacts and integration of investments, complement and provide a context for specific development projects' (p. 113). One of the important observations that they make is that this strategic focus on spatial development has the capacity to shift governance cultures and in

Dominique Decoster, Universite Libre de Bruxelles, Belgium; Valery Michaux, Reims Management School, France; Michael Murray, School of Planning, Architecture and Civil Engineering, Queen's University, Belfast, BT9 5AG, Northern Ireland; Brendan Murtagh, Queen's University, Belfast, Northern Ireland; Catherine Niarchos, Universite Libre de Bruxelles, Belgium; Fabrice Thuriot, Universite de Reims, France; Jim Walsh, National University of Ireland, Maynooth, Ireland. 
this regard the spotlight is cast on the legitimacy, effectiveness and opportunity of local involvement. This attention to a new localism drawing on networked community involvement can enrich spatial planning (Doak \& Parker, 2005). It is a point also underlined by Healey (2004) in her assertion that the delivery potential of spatial strategies is inextricably linked to local specificities comprising the interaction of multiple stakeholders concerned with place quality and territorial development, but who are also appreciative of the wider relations of which they are a part (p. 65).

It is within that context that this article explores the contribution of four development organizations to local development in North West Europe. These are Rural Community Network (RCN) in Northern Ireland, Southside Partnership in the Republic of Ireland, Fondation Rurale de Wallonie (FRW) in Belgium, and the Syndicat Intercommunal d'Etudes et de Programmation de la Region Urbaine de Reims (SIEPRUR) in France. While the specific development remit of each organization reflects particular political-cultural dynamics and contemporary governance configurations, there exists a shared commitment to indigenous development processes at the local scale that seek to overcome market failures, improve capacity and facilitate community empowerment. This agenda fits well with broader observations by Ray (1999a, 1999b) who has argued that within the context of deeper globalization and top-sponsored direction, a belief in local, territorial agency is not entirely misplaced and that capital resources can be created by territories engaged in endogenous development activity.

The discussion draws on action research by the authors, ongoing through to 2007, being funded by the Strategic Planning Action Network (SPAN) of the European Union INTERREG 111B programme. The organizations from the four territories identified above are involved in this project, for which the essential departure points are the European Spatial Development Perspective and the follow-on Spatial Vision for North West Europe. Each document gives explicit recognition to the importance of indigenous development. Our article, in short, seeks to assess the transformational capacity of agency intervention against that element of a much wider European agenda related to territorial cohesion.

The structure of the article is as follows: firstly, we set out the strategic spatial planning context for local development in North West Europe and relate this to the EU-funded SPAN project; secondly, we give a short overview of each of the four development organizations, identified above, and participating in this transnational cooperation project; and thirdly, we conclude by identifying key drivers of organizational capacity for delivering local development as a contribution to deeper European territorial cohesion.

\section{The Strategic Spatial Planning Context for Local Development in North West Europe}

In 2004 the European Commission published its third report on economic and social cohesion located within the context of EU enlargement from 15 to 25 member states. It argues the need to expand investment in physical and human capital to promote overall growth, and expresses concern about the longstanding disparities that give rise to territorial imbalance. The report (European 
Commission, 2004) reveals that the challenges ahead can be described at a number of spatial scales: a centrally positioned European core (pentagon) vis-à-vis a more extensive periphery, ${ }^{1}$ national disparities between main metropolitan areas and the remainder of their respective country, ${ }^{2}$ and regional disparities associated with the sprawl of large urban areas in contrast to the decline of rural areas experiencing a falling population and reduced availability of services. ${ }^{3}$ Within regions, cities and rural areas there are pockets of persistent social deprivation. Strategic spatial planning at transnational and inter-regional levels represents one prominent response of interest to planners in combating these territorial inequalities. Of particular interest here is the European Spatial Development Perspective (ESDP) and the Spatial Vision for North West Europe.

The ESDP (European Commission, 1999) was agreed in Potsdam, Germany in May 1999 at the meeting of the Informal Council of Ministers responsible for Spatial Planning. This brought to a conclusion a planning process that had commenced in 1993. The subtitle of the ESDP: Towards a Balanced and Sustainable Development of the Territory of the European Union captures well this new planning consciousness predicated on closer cooperation by members.

Three policy themes inform the ESDP: the development of a balanced and polycentric urban system ${ }^{4}$ and a new urban-rural relationship; securing parity of access to infrastructure and knowledge; and sustainable development, prudent management and protection of nature and cultural heritages. It is envisaged that these should be worked through not only by European institutions, but also by public bodies at national, regional and local levels. A total of 60 policy options/ principles are presented in the text in order to help explicate these spatial development themes, provide policy choices, and confirm territorial inclusiveness. In the context of this article's interest in local development, an important policy aim is stated to be 'indigenous development giving rise to diverse and productive rural areas'. The follow-on policy options include: the promotion of diversified development strategies with an emphasis on education, training and the creation of non-agricultural jobs; strengthening small and medium-sized towns as focal points for regional development; exploiting the development potential of environmentally friendly tourism; and supporting information exchange between rural areas (pp. 23-24).

Nonetheless, the policy directions being advanced through the ESDP have generated criticism (for example, Richardson, 2000; Hadjimichalis, 2003; Coccossis et al., 2005). There are issues around its strong urban preference as the spatial driver for regional development and the marginalizing of the rural. Its attachment to polycentric development may also have less relevance for the peripheral geographies of Nordic countries and those in south-east Europe in that it does not reflect their particularities of spatial development.

At first glance these concerns can also be identified in the Spatial Vision for North West Europe relating to the United Kingdom, Ireland, Belgium, northern France, Luxembourg, the southern Netherlands and the western part of Germany. This was prepared by a project partnership from these seven member states. It was published in 2000 and is oriented to issues of transboundary and European significance, for example, the positioning of transport axes and development 
corridors. A noteworthy feature is the depiction of four transnational cooperation zones: an inland zone, a central zone, an open zone and an island zone. As argued by Nadin (2002) these are defined according to common problems requiring new project collaborations at the transnational level. The Vision seeks to secure greater economic prosperity and social cohesion within environmental limits and, again, argues that attention should be given to indigenous development. In this regard what is especially interesting about this approach to spatial differentiation is that the envisioned global powerhouse of the polycentric core within the central zone is counterbalanced by different narratives of challenges and potentials ranging from development pressure on the natural environment in some accessible areas to rural depopulation in more peripheral regions. Its initial implementation, through to 2008 as a result of funding reallocations, is being taken forward by the Northwest Europe Community Initiative Programme-one of 10 INTERREG $111 \mathrm{~B}^{5}$ transnational cooperation programmes in Europe.

The appeal, therefore, of the ESDP lies in its role as a 'mother document' (Jensen, 2002, p. 116) to facilitate discussions about difficult and contested issues such as the relationship between EU regional policy, spatial planning and European integration. As noted by Faludi (2006) the ESDP agenda is closely linked with territorial cohesion and at an operational level it is being supported through the work of the European Spatial Planning Observation Network (ESPON) and the Community Initiative INTERREG, one strand of which specifically ties in with the ESDP. The Spatial Vision for North West Europe seeks to provide an application of the ESDP within that context of transnational cooperation. In this vein Graham (1998) has observed more broadly that the diversity of trajectories of change in the past have ensured that Europe has always been characterized by tensions of diversity and integration, and that if diversity is the outcome of past processes, there will also be multiple trajectories of change in the future (p. 313). The ESDP and the Spatial Vision for North West Europe do signpost significant trajectories towards coordinating the spatial dimensions of sectoral policies. Local development, with its sheer breadth of concerns, is one such shared trajectory of change towards that diversity of better and different futures. The SPAN project, belonging to the EU INTERREG 111B (North West Europe) programme, is attempting to take this matter forward.

SPAN $^{6}$ brings together four regions in four EU member states within the North West Europe zone: Wallonia (Belgium), Northern Ireland (United Kingdom), Champagne-Ardenne (France) and Greater Dublin (Ireland). The novel nature of SPAN is that in each of these regions a local development organization ${ }^{7}$ has joined with a university partner to explore civil society participation in the planning of territorial development at local, subregional and regional scales. The project has an overall budget of $€ 4.1$ million, some $60 \%$ of which comes from the EU European Regional Development Fund.

Two themes underpin the work of SPAN partners: (i) strategic territorial planning which is concerned with the harnessing of economic, social, environmental and cultural assets for indigenous development; and (ii) multilevel governance which recognizes the value of collaboration across different levels of institutional and organizational responsibility. Strategic territorial planning, expressed simply, is a structured way to analyse a local situation and map the 
way forward. It is a process that looks forward over a number of years and which seeks to incorporate economic, social, cultural and environmental challenges into a coherent framework. It is a response to the frequent occurrence that treats decisions independently regarding different types of land use (e.g. housing, business, recreation), infrastructure (e.g. transportation, energy) and natural environments (e.g. areas of scientific value, coastal zones, areas of landscape excellence). Traditionally each of these themes has its particular objectives, policies and action plan. In contrast, strategic territorial planning is a collective and participatory process that seeks, through shared processes of reflection, to move towards closer integration.

But strategic territorial planning is also strongly related to different multilevel governance challenges. There are two axes of engagement here. First, there is a vertical governance challenge which must deal with the cooperation, coordination and collaboration activities between local, subregional, regional and national actors and which requires a mix of top-down and bottom-up approaches in order to get close to citizen needs. Second, there is a double horizontal governance challenge that must deal with the cross-over between sectors (e.g. social inclusion, accessibility, spatial planning and economic development), and the crossover between different types of actor (i.e. public bodies, the associational sector and the private sector). The contribution of SPAN in all these matters is to explore how it is possible to break down the many vertical and horizontal barriers between sectors and actors, to develop real capacities for mutual engagement among stakeholders, and to understand which type of governance arrangements work best under which conditions.

Perhaps the important point here in the context of this article is that the momentum of SPAN is inextricably linked to the embeddedness of the practitioner organizations within the institutional layers of local development governance in their member states. Each organization has nurtured a strong capacity to operate within its particular territorial setting and this, in turn, has provided the necessary energy to begin to shift up a gear to transnational collaboration related, for example, to exchange of experience, local development training, and comparative research on the relationship between strategic spatial planning, multilevel governance and local development. Within SPAN the project methodology places great emphasis on local scale action research within the four regional territories that links these practitioner organizations with university expertise and citizen involvement in a shared search to develop new and transferable tools to secure better local development outcomes.

\section{A Case Study of Four Local Development Organizations}

This section of the article reports the manner in which four organizations involved with SPAN contribute to the mobilization of local development in their respective territories. The rationale for the their selection relates to their positioning within each of the spatial development zones comprising the Spatial Vision for North West Europe While the analysis draws out similarities and differences in emphasis, particular attention is given to how organizational activities are given spatial expression. 


\section{Rural Community Network (Northern Ireland)—The Voice of Rural Communities}

Rural Community Network $(\mathrm{RCN})^{8}$ is a Northern Ireland regional voluntary organization established by community groups from rural areas in 1991 to articulate the voice of rural communities on issues relating to poverty, disadvantage and inequality. It receives core funding from central government through the Department of Agriculture and Rural Development with the remainder of its income coming from charitable trusts, membership fees and project income. $\mathrm{RCN}$ has grown from 60 member organizations at its formation to over 500 members in 2006, comprising community groups, Northern Ireland wide voluntary organizations, local authorities, external bodies, consultants and individuals. RCN sees itself as a learning organization with continuous review of its work, training and staff development, and a participative management style. It takes the view that:

- Rural development must be implemented at a variety of geographical scaleslocal, subregional and regional;

- Voluntary participation through a community development process can contribute to better planning and delivery;

- Inequality and sectarian divisions in rural areas can be reduced by community development and the creation of social networks across communities;

- Capacity building to forge new skills related to leadership, mediation and conflict resolution is essential in building community confidence; and

- Openness, accountability and transparency are essential building blocks for the equitable development of rural areas.

Since its inception RCN has been to the forefront of important policy debates relating to rural Northern Ireland. As recorded by Fitzduff (2003) the organization has collaborated with a wide range of other statutory and voluntary agencies to respond to a plethora of rural issues including rural services, water and electricity supplies, Post Office closures, community care, town and country planning, housing, the elderly, women on farms and EU regional aid programmes. It has ensured that an awareness of poverty in rural areas of Northern Ireland has been kept to the fore.

However, $\mathrm{RCN}$ has also recognized that an effective response to these local development challenges requires more than a consultative and lobbying agenda built around meetings, clinics, conferences and publications. From the mid-1990s, $\mathrm{RCN}$ began to take on programme and project administration responsibilities in order to better realize its strategic objectives. Thus, for example, it received funding for initiatives related to the development of rural community tourism, the arts and environmental management. The EU Special Support Programme for Peace and Reconciliation in Northern Ireland and the Border Counties of Ireland ${ }^{9}$ provided an opportunity to consolidate networking activity at the subregional level, to address some of the underlying politico-cultural divisions in rural areas, and to specifically target areas with a weak community infrastructure. Small grants to individual community groups stimulated local initiatives on social inclusion and 
reconciliation. A flagship initiative comprised the Millennium Halls Programme ${ }^{10}$ and allowed RCN to invest in a total of 54 new or refurbished community halls as open and shared venues for rural communities. The project in Northern Ireland ran from 1997 to 2001 with funding of $£ 4.6$ million from the UK Millennium Commission.

In $2005 \mathrm{RCN}$ commenced a major strategic review to better position it for the period 2007-2013. Its initial deliberations recognize the need to locate the future local development activities of the organization within the emergent EU funding arrangements for rural development, and Government strategies related, for example, to social deprivation and equality. There has also been a substantial consultative input from the broader rural constituency and key options are based on recognition that RCN should be recognized for two key areas of activity: first, as an independent rural voice, especially for those in rural society who are most vulnerable, with advocacy informed by research and community action; and second, as a centre of excellence for community development support, including a grant giving capacity to strengthen participation and empowerment. In short, RCN is intent at remaining at the core of community-led rural development in Northern Ireland.

\section{Southside Partnership (Greater Dublin)—A Collective Approach to Tackling Disadvantage}

The Southside Partnership in 2006 is one of 38 Area Partnership Companies in the Republic of Ireland that have been established to tackle socio-economic disadvantage. The Companies are charged with responsibility to work within local communities and to engage with vulnerable groups of people. Southside Partnership was formed in 1995 to deal with severe social deprivation in the Dun Laoghaire/Rathdown area of south Dublin — a district marked overall by very low rates of unemployment, high rates of participation in third-level education, and strong representation in managerial and professional occupations. The geographical isolation of distressed communities and individuals against that backcloth of great affluence points to the often hidden nature of poverty. In the Southside Partnership territory this gives rise to concentrated disadvantage with the local development challenge aptly described as follows:

Taken in isolation, the experience of unemployment, lone parenthood, or disability are hard enough to bear, but when people live in an area of concentrated disadvantage, they may also have to cope with poor housing, bleak landscapes, lack of childcare, distance from services, inadequate public transport, drug dealers in the neighbourhood, increased risk of health problems and poor community morale. The interrelationship between social, economic and environmental issues and the fact they affect the overall life experience of an individual means that a holistic approach is required to tackle them. ${ }^{11}$

Southside Partnership focuses its work in south Dublin on 21 areas with a 2001 estimated population of some 46,000 people. Each area is quite 
Dominique Decoster et al.

distinctive in the challenges being faced and while community development capacity varies, local strategies are devised in partnership with local people to ensure responsiveness and maximize engagement. In addition, there are some 30,000 members of target groups (for example, people with disabilities, Irish Travellers, lone parents) who do not live within these designated geographical areas and who are supported by Southside Partnership. Put simply, its roles are:

- To promote a more coordinated and integrated approach to the delivery of statutory and other services;

- To influence the policies, priorities and budgets of national, regional and local service delivery bodies;

- To pilot new initiatives, including the carrying out of research, with a view to mainstreaming;

- To leverage funds from the Irish government and the European Union to allow for the introduction of new programmes and projects;

- To build the capacity of key target groups thus enabling them to play a more active role in local development governance structures; and

- To support community-based initiatives relating to improved facilities and better access to employment, training, education and childcare. ${ }^{12}$

Southside Partnership is funded through a combination of EU, Central Government, statutory agency and local authority support and is managed by a 23-member board drawn from statutory agencies, trades union and business social partners, local community interests and elected representatives from local government. Its current Implementation Plan 2004-2006 places a strategic emphasis on community development, education and youth development, and services to the unemployed. These themes underline the social mobilization potential of local development, but which, for success, requires the type of longterm commitment being given by Southside Partnership.

\section{Fondation Rurale de Wallonie (Wallonia)—A Champion of Participatory Rural Development}

The Walloon Region is one of three regions that make up the federal Belgium state, the other two being the Flemish Region in the north, and the BrusselsCapital Region in the centre of the country. Within Wallonia there are 262 communes that have district council level, optional responsibilities related to town and country planning, heritage management, economic development including tourism, housing and cultural activities. Rural Wallonia comprises 130 communes (66\% of the region) with the intervention zone of the Fondation Rurale de Wallonie (FRW) ${ }^{13}$ involving 61 communes. In all these contain some 500 villages with a population of almost 413,000 people.

The formation of FRW can be traced back to 1975 when economic crisis in rural Wallonia prompted the establishment of the Fondation pour la Renovation Rurale et la Qualite de Vie du Sud-Est de la Belgique ${ }^{14}$ to promote integrated local development strategies. In 1979 the agency was renamed the Fondation Rurale de 
Wallonie. In line with the wider European interest in rural development in the early 1990s, following the publication by the European Commission of The Future of Rural Society in 1988, the Walloon Parliament adopted a decree on rural development in June 1991. This defined a legislative framework for rural development operations and funding. At the same time the Walloon Government gave its approval to a framework agreement that specified the mission of FWR in line with these provisions.

In 2006 the agency has some 90 staff divided into 10 teams across rural Wallonia charged with promoting living, dynamic villages involving citizen participation in the preparation and implementation of broad based development strategies. FRW acts as a 'go-between' the local population, local government and regional authorities Over 500 projects are being brought forward or have been completed ranging, for example, across new public parks, museum development, low cost housing, community centres, workspace, water and sewage treatment facilities and building restoration. FRW is helping to deliver the EU LEADER+ initiative,${ }^{15}$ rural development training, a heating energy project using forestry byproducts, and the conservation of village heritage and rural habitats. It acts as the Wallonia Carrefour for the dissemination of European information.

The ten Development Officer teams are a crucial element of the FRW approach to rural development, working closely with local government and the local population of each commune. Information sharing and consultation are central features of the planning process. They guide the deliberations of Local Commissions for Rural Development that are required to be established under the 1991 enabling legislation for rural development, and they contribute to the drafting of Programmes Communaux de Developpement Rurale. ${ }^{16}$ Following the approval of each rural development scheme by the Local Rural Development Commission, the local council and the Walloon Government, the Development Officers then assist with project implementation and monitoring. In short, the guiding philosophy of FRW is to place the vitality and drive of those working in the field at the service of engaged local populations.

\section{Syndicat Intercommunal d'Etudes et de Programmation de la Region Urbaine de Reims (Champagne-Ardenne)_Connecting the Urban and the Rural}

The Syndicat Intercommunal d'Etudes et de Programmation de la Region Urbaine de Reims (SIEPRUR) is an association of communes and groups of communes that brings together the elected representatives of Reims and its surrounding rural area. Its planning remit is funded from its own resources, subsidies from the Region and the State, and ongoing assistance from the Agence d'Urbanisme et de Developpement de la Region de Reims. ${ }^{17}$ To better understand the remit of SIEPRUR, it is necessary to have regard to the emergence of new approaches to local governance in France over the past 15 years.

France has a complex multilayered system of public administration, the basic unit of which is the commune. There are 36,782 communes in the country, some $87 \%$ of which have fewer than 2,000 people. In order to achieve economies of scale in service provision communes have increasingly cooperated by creating 
Dominique Decoster et al.

formal alliances referred to as 'communities of communes' in rural areas and 'communities of agglomeration' (urban communities) in urban areas.

Following primary legislation in February 1995, the planning-related 'Voynet' Act in June 1999 reintroduced a framework for territorial cohesion around the concept of the 'Pays', designed to deepen the scope for local cooperation. The Pays approach had actually dated back to the 1970s but was for rural areas only. In 2006 there are some 320 Pays in France with an average population of 70,000 people. This more recent manifestation of spatial policy has facilitated a new and voluntary governance dynamic at the local level by replacing a sectoral and diffuse administrative configuration, with a customized, common and crosssectoral territorial strategy at a coherent geographical scale. A key concern is sustainable development. This is neither a local community, nor an authority, but rather an interface for intermunicipal and interterritorial cooperation between urban and rural areas. It works through a forward-looking dialogue-based planning process that is concerned with long-range development and seeks to involve public bodies, elected representatives and civil society in reaching agreement. In each Pays, a broad based civil society, with (or without) elected representatives, makes up an advisory Development Council to assist with Pays planning and implementation activities. This is a deliberative forum and it does not have authority to make policy decisions.

The Pays manifests itself by two key outputs: a Pays Charter setting out a 10 to 15 year spatial development strategy shared by the partners involved in its preparation; and a Pays Contract comprising a maximum, but possibly renewed, three-year action programme to implement the Charter. What is important is that the Pays, in the main, is not a delivery organization, but rather a mechanism to foster coherent territorial development. Operational responsibilities remain for the most part with the local public administration bodies ie communes, communities of communes and communities of agglomeration.

SIEPRUR is the coordinating support association for the Pays Remois territory in Champagne-Ardenne. The Pays Remois contains 140 communes. It brings together the six urban communes in the 'community of agglomeration' of Reims (currently some 214,000 people) and 134 rural communes in the rural areas surrounding Reims that make up 16 'communities of communes' (currently some 74,000 people). A major development issue is that physical expansion of the city of Reims is constrained because of the surrounding high quality agricultural and vine growing land. A sharp urban-rural land use divide translates in turn into a distinct cultural, and often tension filled, separation between urban and rural elected representatives. The Pays approach was initially promoted in 2001 by city politicians, but secured a consensus with rural representatives on the need to work together at the end of 2002. The drawing-up of the Pays Charter gathered pace in 2003 with the establishment by SIEPRUR of a 'Commission on Rurality' to give expression to local identity through high quality debates. Over a period of 18 months over 60 meetings were convened attended by more than 1,000 people to discuss 19 key topics of local concern including land management, housing construction, and physical infrastructure, not least the impact of an imminent high speed train link with Paris. This process of collective discussion resulted in the completion of the Pays Remois Charter ${ }^{18}$ in 2004 and the agreement to go forward 
with a Pays Contract which was co-signed by the intermunicipal structures in April 2005. These projects concern the rural area, while the urban area is covered by a complementary Agglomeration Contract. Each is co-financed by the Department and/or the Region and by the State, with the bulk of funding coming from the communes or groups of communes.

\section{Conclusion: Organization-led Local Development and European Territorial Cohesion}

In this article, the remit of the local development organizations is given broad definition. The four organizations reviewed above demonstrate a number of significant characteristics that are in broad conformity with the analysis of Halkier et al. (1998). Essentially, they are illustrative of what these authors cite as the "new model of bottom-up intervention' (p. 19): semi-autonomous vis-à-vis central and local government, specific missions executed in a business-like manner, a wide degree of operational freedom, a concern with indigenous development, and combining advisory, financial assistance and public provision activities. However, we take these concerns further in that rather than committing to a solely economic development focus, we see great significance in their broad based local development approach which by its very nature must engage within what Bryson and Crosby (1992) have dubbed 'a shared power world'. These organizations are of the regions within which they are situated and, through processes of collaborative local engagement, connect regional and local place-based perspectives on development. This dynamic is important in the operationalization of the North West Europe Spatial Vision.

The relationship between regional and local development is structured around two significant interdependencies (Hart \& Murray, 2000). First, as noted by Tommel (1997) regions as territorial units have emerged as new actors in European decision making and policy implementation. Their roles in formulating and implementing Structural Funds Operational Programmes and their participation in the relatively small scale, but high profile, Community Initiatives have required the formulation of new multi-level networks of cooperation. These embrace central and local government, reach out to the European Commission, look across to other regions outside the immediate jurisdiction, and focus down on a wide range of local non governmental organizations. A second interdependency relates to the concept of subsidiarity and its counterpart of mobilization whereby effective action requires organizing at the level most appropriate to what is being attempted. In short, there are things that can best be done at the regional scale, for example, the strategic planning of major infrastructure, or the management of inward investment programmes. And at the same time there are development activities best left to organized actions within the constituent areas of any region, for example, community-led revitalization. Local development is not an alternative to regional development, but rather a dimension of public policy that, in concert with development at the regional scale, can secure the optimal use of available resources.

What, therefore, it may be asked, are the key elements that seem to influence organizational capacity within EU member state and transnational local development governance arenas? Our experience, thus far, of working with four 
Dominique Decoster et al.

of the practice-oriented organizations involved with the North West Europe SPAN project, highlights the presence of four key factors:

- Building organizational leadership: In each organization there are people with motivational ability who are prepared not only to 'lead from the front' but also to nurture relationships of trust and respect with staff and board members. They have an intimate knowledge of their political and technical environments, and are comfortable with group behaviour processes internally and externally. So, for example, Rural Community Network in the North West Europe Spatial Vision Open Zone has invested substantially in its organizational culture to ensure that concepts of equality and an appreciation for diversity are at the centre of its practices (Murray \& Murtagh, 2004). The specific context in Northern Ireland is a society emerging from conflict but still with deep ethnoreligious divisions and high levels of spatial segregation in both urban and rural settings. The Rural Community Network approach to local development involves valuing small steps, challenging old social spaces and inviting new ways for people to relate to one another. It is an approach that seeks to enrich the social capital stock of rural communities at a time of considerable rural policy change, more emphasis by Government on mixing, the increasing participation of migrant workers within local labour markets, and the rolling out of the wider peace process on the island of Ireland. The leadership challenge for Rural Community Network revolves around anchoring the organization in its core constituencies and relevant policy environments by developing practical good relations work that can draw in other stakeholder alliances to a wider reconciliation project.

- Nurturing community empowerment: It is now inconceivable that local development initiatives would be brought forward without the input of local communities. Moreover, there is an inextricable link between local development and community development. This is not just about giving citizens an opportunity to voice opinions and concerns, but rather addressing power relationships and supporting people in a process of change. Local development, therefore, is concerned with building community sector infrastructure and embedding this capacity within broader networks of support. The Wallonia case in the North West Europe Spatial Vision Central Zone is very apt in this regard given the adoption of a Contract ${ }^{19}$ by the Walloon Parliament in 2002 that underlines the objective of involving all Walloon citizens in the development of their region. This is well exemplified by the initiative Les plus beaux villages de Wallonie in which over 20 villages are seeking to conserve their architectural heritage, with technical support from FRW, in a combination of locally determined townscape improvement measures, signposting, promotion and events. Each village is a member of this non-profit making association, created in 1994, and which guarantees the authenticity of the communities in the network. An international momentum to this work has emerged over the period from 2000 with new associational linkages being forged in France and Italy. A collective will at the local level, shared by the municipality and the rural community, has helped forge this sense of empowerment. 
- Mobilizing partnership creation: A vast literature exists on the advantages and limitations of partnership approaches to local development, but as noted by Walsh (2004a), they are recognition of the reality that no single organization is capable of responding in a comprehensive manner to problems that result from a combination of local and external factors. Success requires a partnership dynamic which is constructed around an appreciation of the value of collective working, a capacity by partners to influence policy and action in their respective organizations, adaptability to emerging circumstances, good communicative practices between partners, and recognition that it takes time to build confidence for collaborative working. The Pays approach to local development in France is illustrative of these criteria with its emphasis on creating a common vision for spatial development out of new, shared trust practices for working together. In Champagne-Ardenne within the North West Europe Spatial Vision Inland Zone this commenced by drawing in elected representatives and sectoral stakeholders to a new scale, intermunicipal working environment (the Pays). However, before the partnership of urban and rural interests could be formalized, the rural communes felt that they needed space to create a common identity among themselves. They sought first to identify the main challenges facing their areas through a 'Commission on Rurality' that then worked effectively within SIEPRUR and with elected urban representatives in drawing up the Pays Remois Charter. What is important here is that SIEPRUR has established its role as an interface between the various levels of authority. It acts as a network facilitator and as an intermediary for coherence between urban and rural spatial development issues.

- Positioning through consultation-driven strategic planning: Inclusive strategic planning requires that those whom organizational activities seek to benefit are intimately associated with the preparation process. But organizational strategic planning based on consultation also allows development agencies to better position themselves. Thus, for example, in regard to Southside Partnership situated in the Island Zone of the North West Europe Spatial Vision, its Implementation Plan 2004-2006 draws heavily on the insights obtained from a United Vision consultation process commencing in 1999 and engaging 1,000 people in dialogue not only from local communities and communities of interest, but also from statutory agencies. Since 2004, when seeking to ground SPAN in the multilevel governance structures at local authority and national policy-making levels, Southside Partnership convened a series of meetings at these different levels to explore opportunities for linking spatial planning and strategic social planning and deepening local identity in a regional context. Awareness of positioning is critical for success.

To conclude, our analysis of local development organizational capacity translates well into a contribution to the definitional debate in Europe about territorial cohesion and the contribution that can be made by local development. The case study organizations fit well with observations by Ray (2006) that potentially, localities can effect change in their favour, rather than be resigned to being victims of external political and economic forces, that a focus on harnessing local physical and human capital through local development can maximize the retention of 
benefits within a local territory, and that an agenda shaped around on the needs, capacities and perspectives of local people must sit alongside the adoption of cultural, environmental and community values within policy intervention. Moreover, as we identify above, this new concept of territorial cohesion embraces a commitment to strategic territorial planning and multi-level governance (Walsh, 2004b). There are a number of dimensions to the concept of territorial cohesion: ${ }^{20}$

- A concern with the way that spatial and environmental linkages (across both the rural and the urban), economic linkages, social linkages, and cultural linkages combine a capacity to support each other within a territory with a capacity to embrace external connections. In other words, there is attention given to internal and external relationships within spatial settings at different scales: local, regional, national and transnational.

- An emphasis which is, arguably, less on the amount of development in a place, but more on the overall web of relations within which institutions, enterprises and people in one place are linked to institutions, enterprises and people in other places. This emphasis is directly on governance.

- Attempts to make public policy, wherever it is formulated, more integrated as it plays out in particular territories. These efforts support the need for strategic interventions.

While territorial cohesion, rather than spatial development has become the 'name of the game' for the European Commission in the context of securing a Constitution for Europe (Faludi \& Waterhout, 2005), the concept has, arguably, at its core the spatial dimensions of economic, social, cultural and environmental development; it confirms the importance of relationships associated with multilevel governance arenas in which to promote and manage change; and it underlines the need to think strategically within a spatial context. The case of these four SPAN organizations in North West Europe demonstrates that a strong emphasis on the quality and quantity of local development linkages among actors, sectors and scales of territory can profoundly influence agency capacity.

\section{Acknowledgements}

A preliminary version of this article was presented at the 2005 Collegiate Schools of Planning Conference in Kansas City, Missouri, USA. The authors are grateful for the comments received from the session discussant and delegates in this revised article. Guidance from the editor of this journal, Vincent Nadin, and observations provided by two anonymous referees have been very helpful.

\section{Notes}

1. The pentagon area stretches between North Yorkshire in England, Franche-Comte in France, Hamburg in northern Germany and Milan in northern Italy, covers $18 \%$ of the EU15 land area, and accounts for $41 \%$ of population, $48 \%$ of GDP and $75 \%$ of expenditure on R\&D (European Commission, 2004, p. 27).

2. In Ireland, for example, $77 \%$ of national employment in internationally traded services is located within the Greater Dublin Area (Department of the Environment and Local Government, 2002, p. 14). 


\section{Organisational Capacity in North West Europe}

3. Isolated rural areas which are sparsely populated, have an ageing demographic structure, a poor infrastructure endowment, low level of services and a poorly skilled labour market are located largely in south west Portugal, north and north east Spain, central France, Scotland, Finland and Sweden (European Commission, 2004, p. 30).

4. As Waterhout (2002) points out, polycentricity can be defined on the continental, national, regional, urban and peri-urban scales, in situations where the ESDP is dealing with functional relations among towns and rural areas, and as dealing with cooperation within metropolitan areas (p. 86).

5. INTERREG is an EU programme designed to facilitate cooperation between countries and regions as an element of EU cohesion policy. INTERREG 111 runs from 2000 to 2006. Strand A deals with cross-border development, Strand B promotes strategic cooperation at transnational level on spatial planning themes, Strand $\mathrm{C}$ assists cooperation and exchange of experiences between regions.

6. For more information about the SPAN project go to http://www.span-eu.org

7. There are two pilot territories in the Greater Dublin region with different organizational structures participating in SPAN. They are Southside Partnership in the Dun Laoghaire Rathdown County and Meath County Development Board.

8. For further information see www.ruralcommunitynetwork.org

9. This was ratified by the European Commission in 1995 following the paramilitary ceasefires in 1994. Its overall aim is to reinforce progress towards a peaceful and stable society and to promote reconciliation by increasing economic development and employment, promoting urban and rural regeneration, developing cross-border cooperation and extending social inclusion.

10. The Millennium Halls Programme of RCN is more fully detailed as a SPAN significant local development experience at www.qub.ac.uk/ep/research/span/resources.htm

11. Taken from Socio-economic and Demographic Profile of Southside Partnership Area (http://www. southsidepartnership.ie/reports.htm).

12. For a fuller discussion see Southside Partnership: A Record of Achievement-The First Ten Years 19952005.

13. For further information see: www.frw.be

14. This translates as the Foundation for Rural Renovation and Quality of Life for the South East of Belgium.

15. LEADER stands for Links between Actions for the Development of the Rural Economy. LEADER+ runs from 2000 to 2006. It builds on two previous rounds of funding and places emphasis on local development strategies to implement pilot projects around a select number of themes, for example, micro business formation.

16. This translates as Rural Development Municipal Programmes.

17. This translates as Agency for Town and Country Planning and Development of the Reims Region. This agency gathers together key stakeholders within its territory (elected representatives from territorial governance structures at local, department and regional scales, State civil servants, and sectoral and community interests) as a debating forum for the preparation of shared plans for its area. Planning and development activity covers strategic territorial planning, urban planning, and economic, social and cultural development. (See: www.aurr.asso.fr)

18. La Charte du Pays Remois: Identite Rurale dans une Strategie d'Alliances avec la Metropole Urbaine published in June 2004 by the Syndicat Intercommunal de'Etudes et de Programmation de la Region Urbaine de Reims (ISBN 2-952256-0-5).

19. Presidency of the Walloon Government (2002) Contract for the Future of Wallonia: A Civic Approach for a New Form of Governance.

20. Adapted from P. Healey (2002) Key phrase: territorial cohesion, University of Newcastle upon Tyne.

\section{References}

Albrechts, L., Healey, P. \& Kunzmann, K. (2003) Strategic spatial planning and regional governance in Europe, Journal of the American Planning Association, 69(2), pp. 113-129.

Bryson, J. \& Crosby, B. (1992) Leadership for the Common Good: Tackling Public Problems in a Shared Power World (San Francisco, Jossey-Bass Publishers).

Coccossis, H., Economou, D. \& Petrakos, G. (2005) The ESDP relevance to a distant partner: Greece, European Planning Studies, 13(2), pp. 253-264.

Commission of the European Communities (1988) The Future of Rural Society (Luxembourg, Official for the Official Publications of the European Communities). 


\section{Dominique Decoster et al.}

Department of the Environment and Local Government (2002) The National Spatial Strategy 2002-2020, People, Places and Potential (Dublin, The Stationery Office).

Doak, J. \& Parker, G. (2005) Networked space? The challenge of meaningful participation and the new spatial planning in England, Planning Practice and Research, 20(1), pp. 23-40.

European Commission (1999) ESDP_European Spatial Development Perspective: Towards a Balanced and Sustainable Development of the Territory of the European Union (Luxembourg, Office for Official Publications of the European Communities).

European Commission (2004) A New Partnership for Cohesion: Convergence, Competitiveness, Cooperation (Luxembourg, Office for Official Publications of the European Communities).

Faludi, A. (2006) The King is dead-long live the King: why there is no renewed European Spatial Development Perspective and what happens to the ESDP agenda anyhow, Paper presented at the Regional Studies Association International Conference 'Shaping EU Regional Policy: Economic, Social and Political Pressures', Leuven, Belgium, 8-9 June 2006.

Faludi, A. \& Waterhout, B. (2005) The usual suspects: The Rotterdam EU Informal Ministerial Meeting on territorial cohesion, Tijdschrift voor Economische en Sociale Geografie, 96(3), pp. 328-333.

Fitzduff, N. (2003) Foreword, in: J. Greer \& M. Murray (Eds) Rural Planning and Development in Northern Ireland, pp. xvii-xxiii (Dublin: Institute of Public Administration).

Graham, B. (1998) Epilogue: Europe's geographies_diversity and integration, in: B. Graham (Ed.) Modern Europe, pp. $311-317$ (London, Arnold).

Hadjimichalis, C. (2003) Imagining rurality in the new Europe and dilemmas for spatial policy, European Planning Studies, 11(2), pp. 103-113.

Halkier, H., Danson, M. \& Damborg, C. (1998) Regional development agencies in Europe: An introduction and framework for analysis, in: H. Halkier, M. Danson \& C. Damborg (Eds) Regional Development Agencies in Europe, pp. 13 - 25 (London, Jessica Kingsley with Regional Studies Association).

Hart, M. \& Murray, M. (2000) Local Development in Northern Ireland-The Way Forward (Belfast: Northern Ireland Economic Council).

Healey, P. (2004) The treatment of space and place in the new strategic spatial planning in Europe, International Journal of Urban and Regional Research, 28(1), pp. 45-67.

Jensen, O. (2002) Imagining European identity: Discourses underlying the ESDP, in: A. Faludi (Ed.) European Spatial Planning, pp. 339-355 (Cambridge, Lincoln Institute of Land Policy).

Murray, M. \& Murtagh, B. (2004) Equity, Diversity and Interdependence: Reconnecting Governance and People Through Effective Dialogue (Aldershot, Ashgate).

Nadin, V. (2002) Visions and visioning in European spatial planning, in: A. Faludi (Ed.) European Spatial Planning, pp. $121-137$ (Cambridge, Lincoln Institute of Land Policy).

Ray, C. (1999a) Endogenous development in the era of reflexive modernity, Journal of Rural Studies, 15(3), pp. $257-267$.

Ray, C. (1999b) Towards a meta-framework of endogenous development: Repertoires, paths, democracy and rights, Sociologia Ruralis, 39(4), pp. 521-537.

Ray, C. (2006) Neo-endogenous rural development in the EU, in: P. Cloke, T. Marsden \& P. Mooney (Eds) Handbook of Rural Studies, pp. 278-291 (London, Sage Publications).

Richardson, T. (2000) Discourses of rurality in EU spatial policy: The European Spatial Development Perspective, Sociologia Ruralis, 40(1), pp. 53-71.

Stohr, W. (1990) Synthesis, in: W. Stohr (Ed.) Global Challenge and Local Response: Initiatives for Economic Regeneration in Contemporary Europe, pp. 1-19 (London, Mansell).

Tommel, I. (1997) The EU and the regions: Towards a three-tier system of new modes of regulation? Environment and Planning C: Government and Policy, 5(1), pp. 413-436.

Walsh, J. (2004a) Partnership theory and practice, in: J. Walsh \& J. Meldon (Eds) Partnerships for Effective Local Development, pp. 7-28 (Charleroi, Universite Libre de Bruxelles).

Walsh, J. (2004b) Spatial planning for territorial cohesion: Linking the urban and rural domains, in: M. O'Cinneide (Ed.) Territorial Cohesion: Meeting New Challenges for an Enlarged EU, pp. 83-98 (Dublin, Department of Community, Rural and Gaeltacht Affairs).

Waterhout, B. (2002) Polycentric development: What is behind it? in: A. Faludi (Ed.) European Spatial Planning, pp. 83-103 (Cambridge, Lincoln Institute of Land Policy). 